\title{
The Occurrence of Quill Mites (Arachnida: Acariformes: Syringophilidae) on Bee-Eaters (Aves: Coraciiformes: Meropidae: Merops) of Two Sister Clades
}

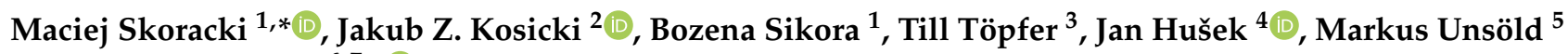 \\ and Martin Hromada $6,7, *$ (D)
}

1 Department of Animal Morphology, Faculty of Biology, Adam Mickiewicz University, Uniwersytetu Poznańskiego 6, 61-614 Poznań, Poland; boszka@amu.edu.pl

2 Department of Avian Biology and Ecology, Faculty of Biology, Adam Mickiewicz University, Uniwersytetu Poznańskiego 6, 61-614 Poznań, Poland; kubako@amu.edu.pl

3 Section Ornithology, Zoological Research Museum Alexander Koenig, Leibniz Institute for the Analysis of Biodiversity Change, Adenauerallee 127, 53113 Bonn, Germany; t.toepfer@leibniz-zfmk.de

4 National Museum, Václavské náměstí 68, 11579 Praha 1, Czech Republic; jan.husek@nm.cz

5 Zoologische Staatssammlung München, Sektion Ornithologie, Münchhausenstr. 21, 81247 München, Germany; unsoeld@snsb.de

6 Laboratory and Museum of Evolutionary Ecology, Department of Ecology, Faculty of Humanities and Natural Sciences, University of Presov, 08001 Prešov, Slovakia

7 Faculty of Biological Sciences, University of Zielona Góra, 65-516 Zielona Góra, Poland

* Correspondence: skoracki@amu.edu.pl (M.S.); hromada.martin@gmail.com (M.H.)

check for
updates

Citation: Skoracki, M.; Kosicki, J.Z.; Sikora, B.; Töpfer, T.; Hušek, J.; Unsöld, M.; Hromada, M. The Occurrence of Quill Mites (Arachnida: Acariformes: Syringophilidae) on Bee-Eaters (Aves: Coraciiformes: Meropidae: Merops) of Two Sister Clades. Animals 2021, 11, 3500. https://doi.org/10.3390/ani11123500

Academic Editors: Joanna N. Izdebska and Leszek Rolbiecki

Received: 8 November 2021 Accepted: 1 December 2021 Published: 8 December 2021

Publisher's Note: MDPI stays neutral with regard to jurisdictional claims in published maps and institutional affiliations.

Copyright: (c) 2021 by the authors. Licensee MDPI, Basel, Switzerland. This article is an open access article distributed under the terms and conditions of the Creative Commons Attribution (CC BY) license (https:/ / creativecommons.org/licenses/by/ $4.0 /)$.
Simple Summary: Parasitic mites of the family Syringophilidae (quill mites) represent the most diverse prostigmatan family associated with birds. Here, we aim (i) to investigate quill mites of a well-defined monophyletic clade of nine bee-eater species, containing mostly migratory African and Asian species; (ii) to establish ectoparasite geographic ranges; and (iii) to discuss patterns of host-parasite relationships and possible host-switches. We have found that despite quill mites being highly specific on the host species or genus level, host-switches may occur, particularly when the ecology of host species overlaps.

Abstract: We studied the quill mite fauna of the family Syringophilidae, associated with bee-eaters. We examined 273 bird specimens belonging to nine closely related species of the genus Merops, representing two phylogenetic sister clades of a monophyletic group. Our examination reveals the presence of two species of the genus Peristerophila, as follows: (1) a new species Peristerophila mayri sp. n. from Merops viridis in the Philippines, M. leschenaulti in Nepal and Sri Lanka, and M. orientalis in Sri Lanka; and (2) P. meropis from M. superciliosus in Tanzania and Egypt, M. persicus in Sudan, Tanzania, Liberia, Senegal, Kenya, and D.R. Congo, M. ornatus in Papua New Guinea, M. philippinus in Thailand, Indonesia and Sri Lanka, and M. americanus in the Philippines. The prevalence of host infestations by syringophilid mites varied from 3.1 to $38.2 \%$. The distribution of syringophilid mites corresponds with the sister clade phylogenetic relationships of the hosts, except for P. meropis associated with Merops americanus. Possible hypotheses for the host lineage shift are proposed.

Keywords: Acari; birds; ectoparasites; host-shift; zoogeography

\section{Introduction}

The family Syringophilidae (Arachnida: Acariformes: Prostigmata: Cheyletoidea) represents the most diverse prostigmatan family associated with birds. To date, there are about 400 described species, and the range of their hosts comprises 24 orders and 95 families from all zoogeographical regions, except Antarctica [1]. All species of this family are permanent and obligatory ectoparasites of birds, and most of them display a high degree of host specificity, being mono- or oligoxenous parasites [2-5]. 
The bee-eaters (Aves: Coraciiformes: Meropidae) comprise a group of 3 genera and up to 28 species (depending on taxonomy), distributed throughout the palaeotropics and southern Eurasia, and Oriental and Australian region (itself, without Oceania). They are found in habitats ranging from dry savannas to rainforests [6-8]. Despite the highest recent diversity of bee-eaters in Africa (22 species), the origin of this family possibly lies in Asia from where bee-eaters dispersed to Africa, then to other regions, and even back to Asia $[9,10]$.

Previous records of syringophilid mites associated with bee-eaters include four species: two species of the genus Syringophilopsis Kethley, 1970 (S. albicollisi Skoracki and Dabert, 2000 and S. melittophagi Skoracki and Dabert, 2001), and two species of the genus Peristerophila Kethley, 1970 (P. meropis Skoracki et al. 2017 and P. hirundinis Skoracki et al. 2020) [11-14].

Here, we aim to (i) investigate quill mites of a well-defined monophyletic clade of nine bee-eater species containing mostly migratory African and Asian species [9]; (ii) establish ectoparasite geographic ranges; and (iii) discuss patterns of host-parasite relationships and possible host switches. This paper is the continuation of the studies on syringophilid mites parasitizing poorly explored birds of the family Meropidae [13,14].

\section{Materials and Methods}

The mite material used in this study was collected according to the technique proposed by Skoracki (2011) [3] from quills of under-tail coverts of dry bird skins housed in the following ornithological collections: Bavarian State Collection of Zoology (Munich, Germany) (ZSM), Royal Museum for Central Africa (Tervuren, Belgium) (RMCA), Zoological Research Museum Alexander Koenig (Bonn, Germany) (ZFMK), National Museum, Nairobi, Kenya (NMK), and National Museum, Prague, Czechia (NMP).

We investigated all nine species of the monophyletic host clade, as identified by Marks et al. [9] (Figure 1). A total of 273 individuals of Merops americanus $(n=8)$, M. apiaster $(n=75)$, M. leschenaulti $(n=13), M$. orientalis $(n=32), M$. ornatus $(n=25), M$. persicus $(n=68), M$. philippinus $(n=8), M$. superciliosus $(n=34)$, and M. viridis $(n=10)$ were examined for the presence of quill mites of the family Syringophilidae. From each bird specimen, we removed about 5-7 under-tail coverts which are commonly occupied by Peristerophila mites on the Merops hosts [13]. All collected feathers were checked under the stereomicroscope and opened using fine forceps. Infested feathers were placed in Eppendorf's tubes with Nesbitt's solution at $40{ }^{\circ} \mathrm{C}$ for about $24 \mathrm{~h}$, and then mites were mounted on microscope slides in Hoyer's medium. Slide-mounted mites were examined under a light microscope (ZEISS Axioscope2 ${ }^{\mathrm{TM}}$; Carl Zeiss AG, Jena, Germany) equipped with DIC optics and camera lucida.

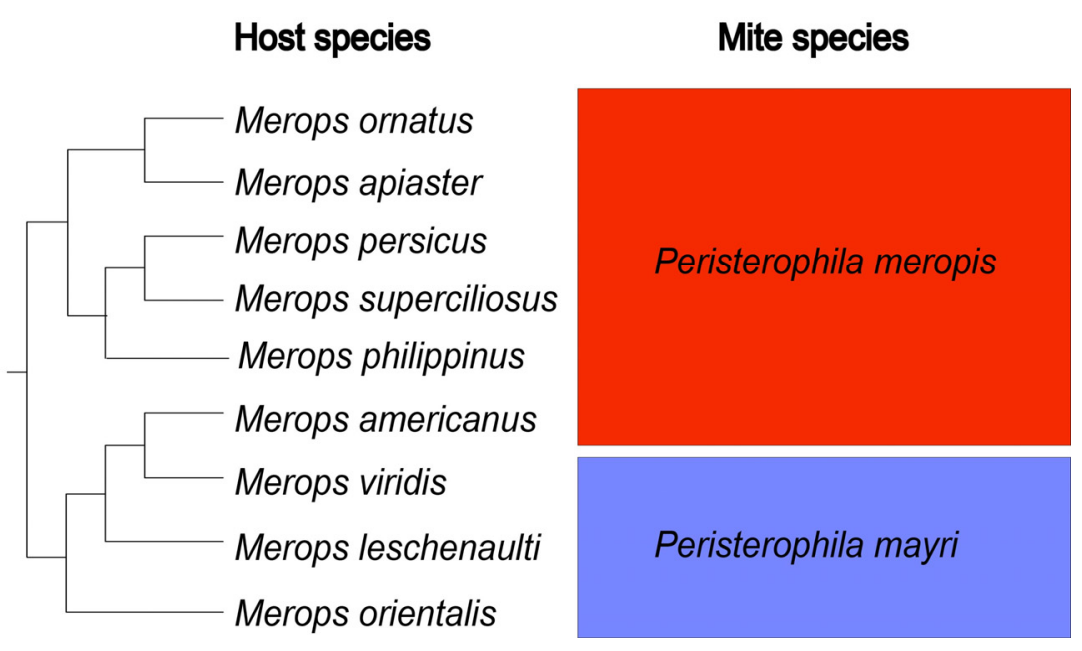

Figure 1. Phylogenetic reconstruction of the bee-eater lineage under study (according to Marks et al. [9]) and associated quill mite species. 
In the descriptions, the idiosomal setation follows Grandjean [15], as adapted for Prostigmata by Kethley [16]. The nomenclature of leg chaetotaxy follows that proposed by Grandjean [17]. Measurements (ranges) for paratypes are given in parentheses following data for the holotype. All measurements are given in micrometers. Depositories of mite specimens are given using the following abbreviations: AMU-Adam Mickiewicz University, Department of Animal Morphology, Poznan, Poland; ZSM-Bavarian State Collection of Zoology, Munich, Germany.

To visualize host phylogeny, a tree was constructed based on data available from http:/ / birdtree.org/ (accessed on 28 October 2021) [18], using the "Ericson All Species tree" with 1000 randomly generated trees. Currently, this tool is widely used in bird evolutionary ecology studies (e.g., $[19,20]$ ), including the investigation of the host phylogenies of bird parasites $[21,22]$. The most credible tree was then determined using TreeAnnotator v1.8.2 in the software BEAST v1.8.2 [23]. The consensus tree was then graphically adjusted in FigTree v1.4.2 [24].

Host data ranges were taken from BirdLife International [25]. The map was drawn using QGIS 3.16 software (Open Source Geospatial Foundation, Beaverton, Oregon, United States) with WGS 84 geographical projection.

\section{Results}

\subsection{Species Composition}

In total, we investigated 273 host individuals belonging to nine Merops species, of which 56 specimens $(21.1 \%)$ were infested by quill mites, whose prevalence varied from $3.1 \%$ to $38.2 \%$ (Table 1 ).

Table 1. Peristerophila quill mites found on examined Merops host species and index of prevalence; $\left({ }^{*}\right)$ data from Skoracki et al. [13].

\begin{tabular}{|c|c|c|c|}
\hline $\begin{array}{l}\text { Peristerophila Quill } \\
\text { Mite Species }\end{array}$ & Merops Hosts & Origin of Host Specimens (Collection) & $\begin{array}{l}\text { Host Examined/Infested; Index } \\
\text { of Prevalence (IP); Confidence } \\
\text { Interval 95\% - Sterne (CI) }\end{array}$ \\
\hline P. meropis & M. ornatus & Papua New Guinea (ZSM) & 25/4; IP 16.0\%; CI 5.7-35.7 \\
\hline P. meropis & M. apiaster ${ }^{(*)}$ & $\begin{array}{c}\text { Spain, France, Gibraltar, Italy, Macedonia, } \\
\text { Romania, Bosnia and Herzegovina, Greece, } \\
\text { Turkey, Russia, Azerbaijan, Pakistan, } \\
\text { Morocco, Tanzania, Kenya (ZSM, NMK) }\end{array}$ & 75/22; IP 29.3\%; CI 20-40 \\
\hline P. meropis & M. persicus & $\begin{array}{l}\text { Sudan, Tanzania, Liberia, Senegal, Kenya, } \\
\text { D.R. Congo (ZSM, RMCA) }\end{array}$ & 68/10; IP 14.7\%; CI 7.8-25.6 \\
\hline P. meropis & M. superciliosus & Egypt, Tanzania (ZSM, RMCA) & 34/13; IP 38.2\%; CI 23.2-56.0 \\
\hline P. meropis & M. philippinus & Thailand, Sri Lanka, Indonesia (ZSM, NMP) & 8/3; IP 37.5\%; CI 11.1-71.1 \\
\hline P. meropis & M. americanus & Philippines: Luzon (ZFMK) & 8/3; IP 37.5\%; CI 11.1-71.1 \\
\hline P. mayri sp. n. & M. viridis & Philippines: Luzon (ZSM) & 10/1; IP 10.0\%; CI 0.5-44.7 \\
\hline P. mayri sp. n. & M. leschenaulti & Nepal, Sri Lanka (ZSM) & 13/2; IP 15.4\%; CI 2.8-43.4 \\
\hline P. mayri sp. n. & M. orientalis & Sri Lanka (ZSM) & $32 / 1 ;$ IP $3.1 \%$; CI 0.2-16.6 \\
\hline
\end{tabular}

Abbreviations: NMK—National Museum, Nairobi, Kenya; RMCA—Royal Museum for Central Africa, Tervuren, Belgium; NMP—National Museum, Praha, Czech Republic; ZFMK-Zoological Research Museum Alexander Koenig, Bonn, Germany; ZSM-Bavarian State Collection of Zoology, Munich, Germany.

We detected two quill mite species of the genus Peristerophila: P. mayri sp. n. and P. meropis (Skoracki et al., 2017). Their occurrence on the respective hosts corresponds with phylogenetic relationships within the genus Merops, as identified by Marks et al. [9]: the subclade including M. ornatus, M. apiaster, M. persicus, M. superciliosus, and M. philippinus is infested by P. meropis, and the subclade including $M$. viridis, M. leschenaulti, and M. orientalis 
is infested by P. mayri. Unexpectedly, P. meropis is found on M. americanus belonging to the second subclade (Figure 1).

We describe a new mite species, Peristerophila mayri sp. n., infesting quill feathers of three bee-eater species: Merops viridis, $M$. leschenaulti, and $M$. orientalis. The other five analyzed species, i.e., $M$. americanus, $M$. ornatus, $M$. persicus, $M$. philippinus, and $M$. superciliosus, represent new host species for the recently described Peristerophila meropis (Table 1).

\subsection{Systematics}

Family_Syringophilidae Lavoipierre, 1953.

Subfamily—Syringophilinae Lavoipierre, 1953.

Genus-Peristerophila Kethley, 1970.

3.2.1. Peristerophila mayri Skoracki and Hromada sp. $\mathrm{n}$.

Female, Heteromorphic Form, Holotype

Description. Total body length 1120 (1100-1150 in four paratypes). Gnathosoma. Stylophore apunctate, covered with longitudinally striate ornament, 155 (140-155) long. Movable cheliceral digit 100 (100-105). Each medial branch of peritremes with two or three chambers, each lateral branch with four chambers. Infracapitulum apunctate. Idiosoma. Propodonotal shield weakly sclerotised, apunctate, divided into two lateral sclerites bearing bases of setae ve and si and unpaired narrow medial sclerite. Setae ve and si subequal in length. Bases of setae $c 1$ situated posterior to level of setal bases $s e$, setae $c 2$ situated anterior to level of setal bases $s e$. Hysteronotal shield absent. Setae $d 1, d 2$, and $e 2$ subequal in length Pygidial shield well developed, apunctate, with rounded anterior margin. Genital ( $g 1-g 2)$ and pseudanal (ps1-ps2) setae subequal in length. Genital plate absent. Length ratio of setae ag1:ag2:ag3 4.6:1:4.6-5.2. Coxal fields I punctate, II-IV sparsely punctate. Setae $3 c$ 3-4 times longer than $3 b$. Legs. Fan-like setae $p^{\prime}$ and $p^{\prime \prime}$ of legs III-IV with 11-13 tines. Tarsi I densely punctate, II-IV sparsely punctate. Setae $t c$ "III-IV about twice as long as tc'III-IV. Apodemes I 110 (110-120) long, apodemes II 50 (45-50) long. Lengths of setae: ve 20 (20-25), si 25 (25-30), se 260 (255), c1 (220-225), c2 235 (220-245), d1 235 (220-235), d2 255 (230-255), e2 245 (235-255), f1 20 (20), f2 (280-290), h1 20 (20-25), h2 (330), ag1 115 (110-125), ag2 25 (25), ag3 130 (125), 3635 (35-40), 3c 135 (105-125), tc' III-IV 35 (25-35), tc"III-IV 75 (70-75), ps1 and ps2 15 (12-15), g1 and g2 12 (12-15), $l^{\prime} R I I I 40$ (35-40), and $l^{\prime} R I V 30$ (25-30) (Figures 2 and 3).

Homeomorphic Female and Male

Not found.

Type Material

Female holotypes and four female paratypes from Blue-throated Bee-eater Merops viridis Linnaeus (Meropidae); Philippines: Luzon Isl., 30 August 1890 (host specimen in the ZSM, uncatalogued).

Type Material Deposition

All type specimens are deposited in the AMU (reg. no. AMU-SYR.608), except one female paratype, which is deposited in the ZSM (reg. no. ZSMA-20190423).

\section{Additional Material}

Ex Chestnut-headed Bee-eater Merops leschenaulti (host in the ZSM, uncatalogued), Nepal: Hitara, 22 March 1962, coll. W. Lagew; two females (heteromorphic form - HET) deposited in the AMU (reg. no AMU-SYR. 598) and one female (HET) in the ZSM (reg. no. ZSMA20190424). Ex the same host species (host in the ZSM, uncatalogued); Sri Lanka: Anuradhapura, 6 January 1905, coll. Doflein; three females (HET) deposited in the AMU (reg. no AMU-SYR. 597) and one female (HET) in the ZSM (ZSMA20190424). 

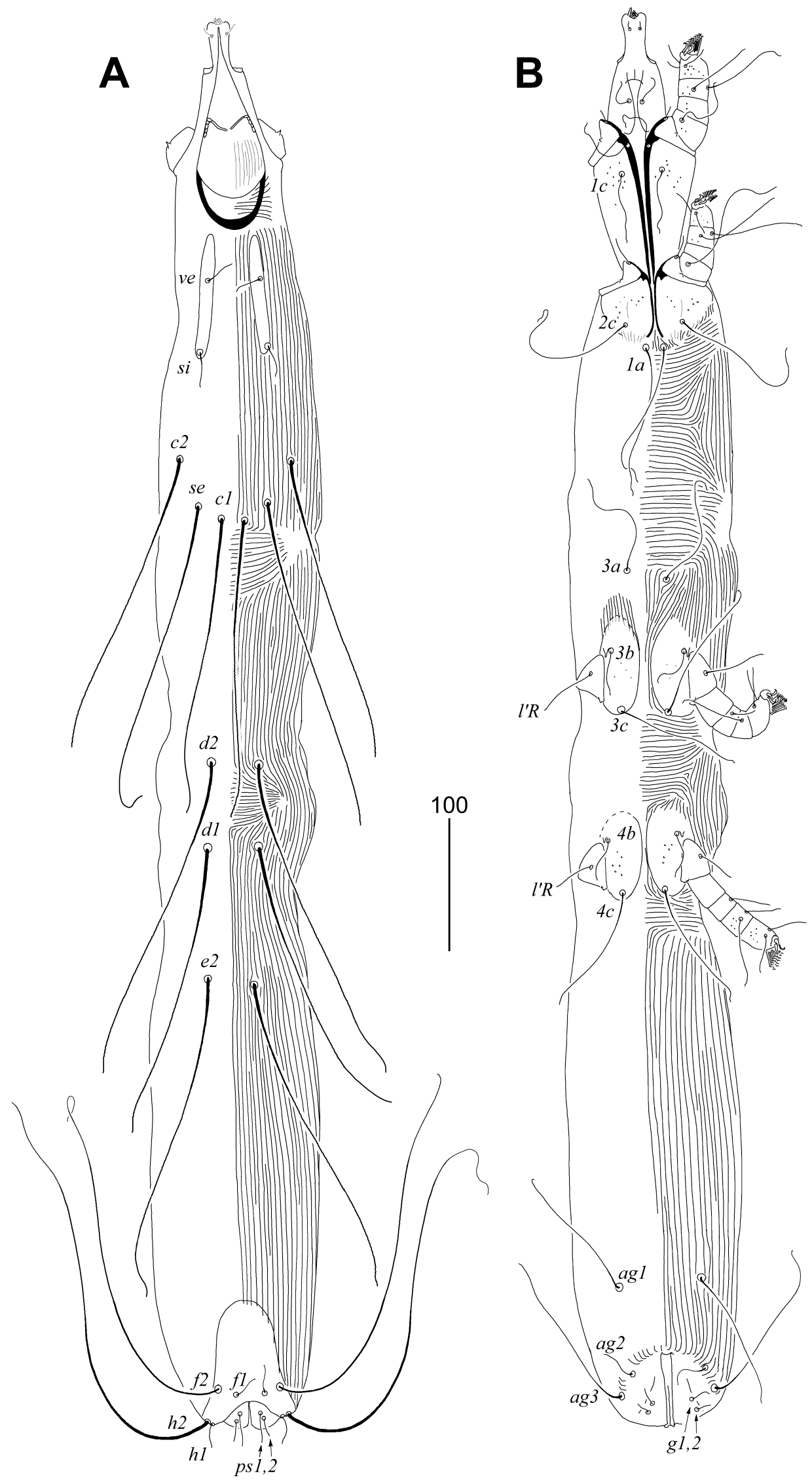

Figure 2. Peristerophila mayri Skoracki and Hromada sp. n., female. (A)—dorsal view; (B)— ventral view. 


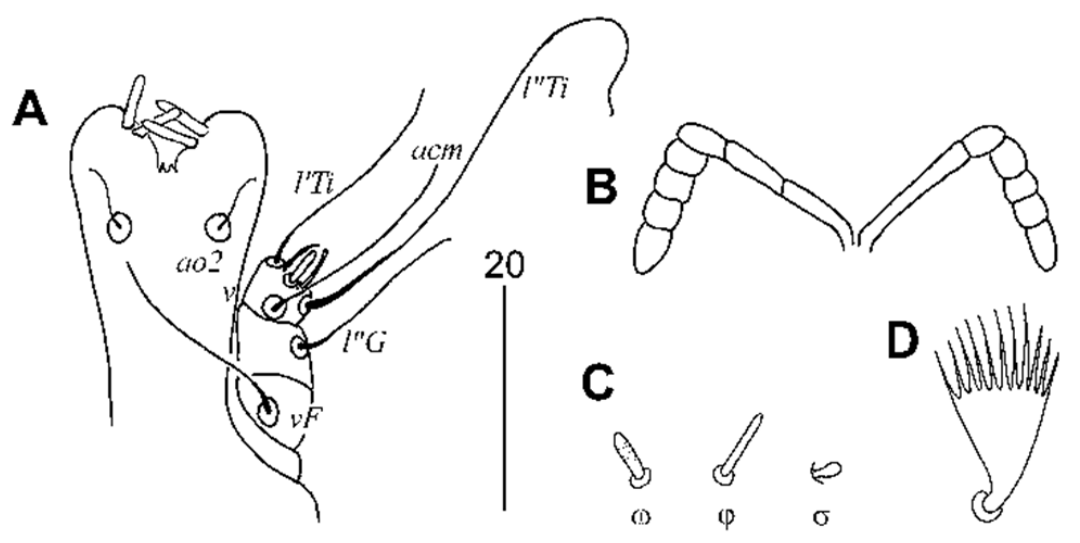

Figure 3. Peristerophila mayri Skoracki and Hromada sp. n., female. (A)—gnathosoma in ventral view; (B)—peritremes; (C)—solenidia of leg I; (D)—fan-like seta p'III.

Ex Little Green Bee-eater Merops orientalis (host in the ZSM, uncatalogued); Sri Lanka: Anuradhapura, 7 January 1905, coll. Doflein; two females (HET) deposited in the AMU (reg. no. AMU-SYR.578).

Habitat

Quills of under- and upper-tail covers and contour feathers of cloaca region.

Etymology

This species is named in honor of Ernst Walter Mayr (1904-2005), arguably the most preeminent evolutionary biologist of the twentieth century. Mayr's contributions during the course of his remarkable life are manifold; among these, he had a lifelong special interest in ornithology and biogeography (e.g., [26]). When investigating the evolution of populations and species, he also referred to bee-eaters studied in this paper in his works (e.g., [27]).

\section{Differential Diagnosis}

Peristerophila mayri sp. n. is morphologically most similar to P. coraciidus Skoracki, Hromada et Sikora, 2020, described from Dollarbird Eurystomus orientalis (Coraciidae) from Papua New Guinea [28]. In females of both species, the hysteronotal shield is absent, and each medial branch of the peritremes has two or three chambers, whereas each lateral branch has four chambers. This new species differs from $P$. coraciidus by the following features: in heteromorphic females of P. mayri, the medial propodonotal shield is present; the tarsal fan-like setae of legs III and IV have 11-13 tines; genital ( $g 1-g 2)$ and pseudanal (ps1-ps2) setae are subequal in the length; the lengths of setae ag1, ag2, and ag3 are 110 125,25 , and 125-130, respectively; the pygidial shield is apunctate, well developed and with the rounded anterior margin. In heteromorphic females of $P$. coraciidus, the medial propodonotal shield is absent; the tarsal fan-like setae of legs III and IV have 17-19 tines; genital setae $(g 1-g 2)$ are $4-5$ times longer than pseudanal setae ( $p s 1-p s 2)$; the lengths of setae $a g 1, a g 2$, and $a g 3$ are 180-265, 65-85, and 255-265, respectively; the pygidial shield is punctate and reduced to small region bearing bases of setae $f 1$ and $f 2$, with indiscernible anterior margin.

\subsubsection{Peristerophila meropis (Skoracki, Hromada et Sikora, 2017)}

Castosyringophilus meropis Skoracki et al., 2017: 2, Figs 1 and 2.

Peristerophila meropis, Skoracki et al. 2020: 1816 [new combination].

Type host: Merops apiaster (Meropidae). 


\section{Hosts and Distribution}

European Bee-eater Merops apiaster from Spain, France, Gibraltar, Italy, Macedonia, Romania, Bosnia and Herzegovina, Greece, Turkey, Russia, Azerbaijan, Pakistan, Morocco, Tanzania, and Kenya [13]; Rufous-crowned Bee-eater Merops americanus (new host) from the Philippines, Rainbow Bee-eater Merops ornatus Latham (new host) from Papua New Guinea, Olive Bee-eater Merops superciliosus (new host) from Egypt and Tanzania; Blue-cheeked Bee-eater Merops persicus (new host) from Sudan, Tanzania, Liberia, Senegal, Kenya, and D.R. Congo, and Blue-tailed Bee-eater Merops philippinus from Thailand, Indonesia, and Sri Lanka (current study).

Habitat

Quills of under- and upper-tail covers, lesser wing coverts, back contour feathers, and contour feathers of cloaca region.

New Material Examined

There were 2 females (heteromorphic form - HET) and 1 male from Merops superciliosus (host in the ZSM; reg. no. 64.909); Tanzania: Pwani Region, Kibaha District, Soga, 10 September 1960, coll. Th. Andersen; all mite specimens deposited in the AMU (reg. no. AMU-SYR.599), except 1 female (HET) which is deposited in the ZSM (reg. no. ZSMA20190418). There were 3 females (HET), 2 males, 7 tritonymphs, 6 protonymphs, and 2 larvae from the same host species (host in the ZSM; uncatalogued); Egypt: near Lake Qarun, 20 March 1989, coll. U. Norra; all mite specimens deposited in the AMU (reg. no. AMU-SYR. 599B), except 1 female (HET), 1 tritonymph, and 2 protonymphs in the ZSM (reg. no. ZSMA20190419).

There were 7 females (HET), 1 female (homeomorphic form - HOM), 1 male, 3 tritonymphs, 3 protonymphs from Merops persicus (host in the ZSM; reg. no. 12.2275, male); Sudan: area of White Nil, 25 February 1912, coll. Hesselberger; all mite specimens deposited in the AMU (reg. no. AMU-SYR.845), except 2 females (HET) in the ZSM (reg. no. ZSMA20190420). There were 2 females (HET) from the same host species (host in the ZSM; reg. no. 64.906, male); Tanzania: Pwani Region, Kibaha District, Soga, 30 January 1962, coll. Th. Andersen; all mite specimens deposited in the AMU (reg. no. AMU-SYR. 740B). There was 1 female (HET), 3 protonymphs from the same host species (host in the ZSM; reg. no. 64.907, female); Tanzania: Dodoma District, Bahi, alt. 3000ft, 6 March 1953, coll. Th. Andersen; all mite specimens deposited in the AMU (reg. no. AMU-SYR.740). There was 1 female (HET) from the same host species (host in the ZSM; reg. no. 08.661); Liberia: "Pessyland", 1909, coll. J. Scherer; mite specimen deposited in the AMU (reg. no. AMU-SYR.749). There were 2 females (HET) from the same host species (host in the ZSM; reg. no. A659); Senegal: 1837, no other data; all mite specimens deposited in the AMU (reg. no. AMU-SYR.741). There was 1 female from the same host species (host in the RMCA; reg. no. 97829/D147, male); Kenya: 7 January 1918, coll: van Somevn; specimen deposited in the AMU (reg. no. AMU-SYR.743). There were 4 females (HET), 4 females (HOM), 1 male, 8 tritonymphs, 4 protonymphs, 5 larvae from the same host species (host in the RMCA; reg. no. 43985/D1); D.R. Congo: Katanga Prov., Kadima, February 1948, coll. Dewit; all mite specimens deposited in the AMU (reg. no. AMU-SYR.742). There were 2 females (HET) from the same host species (host in the RMCA; reg. no. 7964/D135); D.R. Congo: Bas Congo Prov., 1915, coll. van Saughem; all mite specimens deposited in the AMU (reg. no. AMU-SYR.748). There were 3 females (HET), 1 larva from the same host species (host in the RMCA; reg. no. 9766/D135); D.R. Congo: Bas Congo Prov., 15 February 1922, coll. Schahnden; all mite specimens deposited in the AMU (reg. no. AMU-SYR.747). There were 1 female (HET), 2 males from the same host species (host in the RMCA; reg. no. 36649/D146); D.R. Congo: Orientale Prov., Ituri, 7 November 1939, coll. Lepersonn; all mite specimens deposited in the AMU (reg. no. AMU-SYR.744).

There were 2 females (HET), 3 larvae from Merops philippinus (host in the NMP; reg. no. P6V 102636); Thailand: Phuket, no other data; all mite specimens deposited in the AMU 
(reg. no. AMU-SYR.1001). There were 5 females (HET) from the same host species (host in the ZSM; reg. no. A661/V341); Sri Lanka: Maddawadi, 9 January 1905, coll. F. Doflein; all mite specimens deposited in the AMU (reg. no. AMU-SYR.1002). There were 4 females (HET) from the same host species (host in the ZSM; reg. no. 25.94/V343); Indonesia: Java, no other data; all mite specimens deposited in the AMU (reg. no. AMU-SYR.1003).

There were 6 females (HET), 2 tritonymphs, 4 protonymphs, 9 larvae, from Merops ornatus (host in the ZSM; reg. no. 13.97/V325); Papua New Guinea: Morobe Prov., near Finschhafen, coll. Hahl; all mite specimens deposited in the AMU (reg. no. AMU-SYR.877), except 1 female (HET) in the ZSM (reg. no. ZSMA20190421). There were 2 females (HET), 1 male, 1 tritonymph, 1 protonymph from the same host species (host in the ZSM; reg. no. 10.120/V326); Papua New Guinea: Madang Prov., Stephansort, coll. M. Hofwokel; all mite specimens deposited in the AMU (reg. no. AMU-SYR.877B). There were 1 female (HET), 1 male, 1 tritonymph, 1 protonymph, 1 larva from the same host species (host in the ZSM; reg. no. 11.671/V323); Papua New Guinea: 17 March 1910, coll. L. Wiedenfeld; all mite specimens deposited in the AMU (reg. no. AMU-SYR.877C). There was 1 female (HET) from same host species (host in the ZSM; reg. no. 11.676/V324); Papua New Guinea: August 1910, coll. L. Wiedenfeld; mite specimen deposited in the AMU (reg. no. AMU-SYR.877D).

There were 12 females (HET) and 2 tritonymphs from Merops americanus (host in the ZFMK; reg. no. ZFMK_ORN_1965.814/B3); Philippines: Luzon Isl., Abra Prov., May 1965, coll. unknown; all mite specimens deposited in the AMU (reg. no. AMU-SYR.594). There were 3 females (HOM) and 3 tritonymphs from the same host species (host in the ZFMK; reg. no. ZFMK_ORN 1965.813/B2) and locality, April 1965, coll. unknown; all mite specimens deposited in the AMU (reg. no. AMU-SYR.594B). There were 1 female (HET), 1 male, 5 tritonymphs, 4 protonymphs, 3 larvae from same host species (host in the ZFMK; reg. no. ZFMK_ORN 1966.1209/B1); Philippines: Mindoro Isl., July 1964, coll. Bregulla; all mite specimens deposited in the AMU (reg. no. AMU-SYR.594C).

\section{Discussion}

Syringophilid mites are tightly associated with their hosts, where most of them represent mono- or oligoxenous species limited to a particular species or group of phylogenetically closely related hosts $[3,4]$. Because the biology of these obligate and permanent parasites is heavily linked to their avian hosts, their diversification pattern often reflects those of their hosts according to the old, but still actual rules of Fahrenholz [29] and Eichler [30].

In our study, birds belonging to two sister clades of bee-eaters are infested by two species of syringophilid mites (Figures 1 and 4), which shows that the occurrence of Peristerophila mites indeed tightly corresponds with the phylogenies of their avian hosts, except for the presence of Peristerophila meropis on Merops americanus.

Until recently, M. americanus was treated as a subspecies of the Blue-throated Bee-eater $M$. viridis, i.e., M. viridis americanus [9,31-34]. However, recently, this species was elevated to a full species, the Rufous-crowned Bee-eater [7,8,35-37]. The geographic range of $M$. viridis stretches from S China, Thailand, and Indochina to Sumatra, Borneo, and Java, whereas M. americanus is confined to the Philippines, thus, they are vicariants $[7,36]$.

We are describing an interesting situation, when two closely related host species, considered until recently to be subspecies of one species, are parasitized by different ectoparasitic quill mites. We suggest the following hypothesis why M. americanus is parasitized by $P$. meropis, a quill mite species typical for the sister bee-eater subclade: $M$. americanus occurs sympatrically with $M$. philippinus on the Philippines archipelago (Figure 4), where they often dwell in the same habitats. Since M. philippinus is a highly colonial species with tens or hundreds of pairs breeding together, they sometimes form mixed colonies with other local bee-eater species. Both M. philippinus and M. americanus breed in ground nest-burrows [38,39] that might be re-used over the years; it is also probable that different species use the same hole. Thus, the infestation of M. americanus by 
P. meropis could be explained by a host-switch between the two sympatric bee-eater species via their colonial nesting sites.

Due to the host phylogenetic affinities, it seems obvious to expect that $M$. americanus should be parasitized by P. mayri; however, it is not possible to speculate at the moment, whether P. mayri, maybe once infesting $M$. americanus and/or its common ancestor with $M$. viridis, was outcompeted when occurring sympatrically with $M$. meropis in the same habitat and host (Figures 1 and 4). More relevant data on the biology and ecology of both ectoparasites and their hosts are needed.

Interestingly, there is another, even more distantly related bird species parasitized by Peristerophila meropis living sympatrically on the Philippines-the Collared Kingfisher Todiramphus chloris (Coraciiformes: Alcedinidae) [26]—which, besides nest-holes excavated in arboreal termitaria, rotten tree trunks, etc., also breeds in earth banks and in the ground, sometimes in nest-burrows excavated by another bird species [40]. Until now, it is the only known non-meropid host of this widespread quill mite taxon. However, for the time being, it is not possible to conclude if this kingfisher is another example of an isolated host-switching event, or P. meropis can be established also on other kingfishers, without detailed investigations of quill mites on other related hosts.

Mapping the ranges of both investigated quill mite species enabled us also to denote their zoogeographic demarcations. Easternmost boundaries of $P$. mayri range are within the classical Wallace line (after Huxley), delineated with the extent of land at the time of the last glacial maximum. Hosts of P. mayri are residents $[6,8,9]$. On the other hand, the range of $P$. meropis is crossing these natural boundaries as far as to Australia; all hosts of $M$. meropis but $M$. americanus (which is the only species from different clade) are migratory, some of them long-distance migrants $[6,8,9]$.

Another interesting fact in our parasite-host study system is not only the relatively high prevalence of infestation, compared to other wild avian taxa [21,41-47], but a situation when actually all taxa in the whole host clade are parasitized by quill mites. We never recorded a similar situation during our studies of quill mites, it is rather usual that some hosts, despite being sufficiently sampled, are not parasitized [21,42-44]. We expect that such high prevalence and presence on all host species are related to bee-eaters high sociality, when up to hundreds of pairs are breeding in the same colony; cooperative breeding, when, besides parents, several helpers are participating in the raising of the offspring in the nest-burrow; and finally, bee-eaters tendency to perch often touching each other $[6,8,38,39]$. 


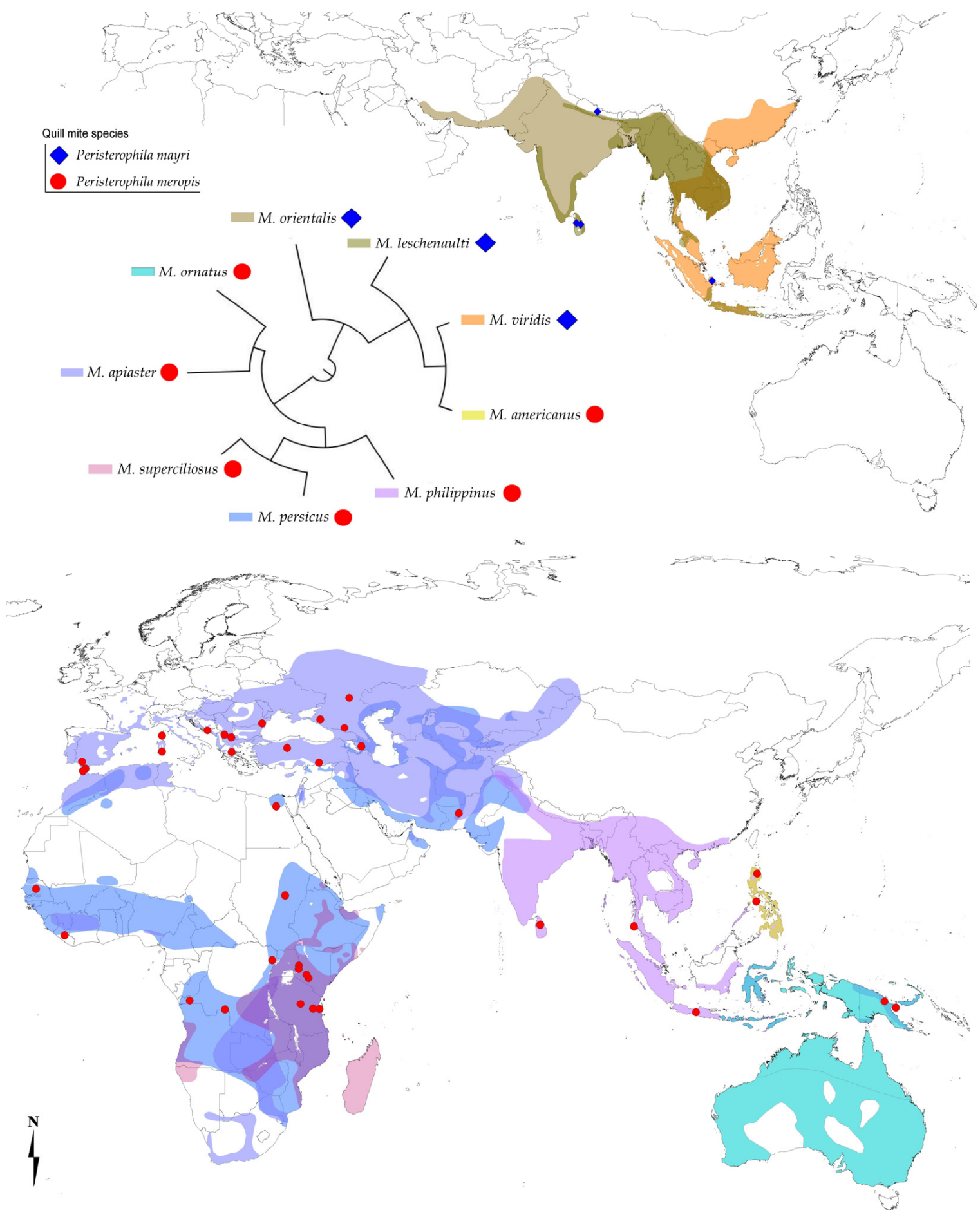

Figure 4. Phylogeny of the Merops bee-eater lineage under study, the species' geographic ranges and recorded localities for the two Peristerophila quill mite species (subclades according to Marks et al. [9], adjusted according to Clements et al. [7]; Winkler et al. [8]).

Author Contributions: Conceptualization, M.S. and M.H.; methodology, M.S., M.H. and J.Z.K. and B.S.; investigation, M.S., M.H., J.Z.K. and B.S.; resources and material collection, M.S., M.H., B.S., T.T., J.H. and M.U.; writing—original draft preparation, M.S., M.H., J.Z.K. and B.S.; writing-review and editing, M.S., M.H., T.T. and J.H.; supervision, M.S. and M.H. All authors have read and agreed to the published version of the manuscript. 
Funding: This research was funded by Slovak Academic Information Agency, SAIA, n.o. 2021 to MS, Slovak Research and Development Agency, APVV-16-0411 and Agency of the Ministry of Education, Research and Development, and Sport of the Slovak Republic and Slovak Academy of Sciences, VEGA - 1/0876/21 to M.H and M.S.

Institutional Review Board Statement: Ethical review and approval were waived for this study, due to the use of only dead animals (specimens deposited in the ornithological collection).

Data Availability Statement: All necessary data (such as localities) are available in the text of this article.

Acknowledgments: We would like to thank Idle Farah, Esther Kioko, and Peter Njoroge from National Museum, Nairobi (Kenya) and Alain Reygel from Royal Museum for Central Africa, Tervuren (Belgium) for making available samples of dry bird skins for the examination of quill mites towards the present study the present study. We also thank Mark Balman (BirdLife International, Cambridge, UK) and NatureServe (Arlington, USA) for kindly providing us with digitalized distribution maps of all host species.

Conflicts of Interest: The authors declare no conflict of interest. The funders had no role in the design of the study; in the collection, analyses, or interpretation of data; in the writing of the manuscript, or in the decision to publish the results.

\section{References}

1. Zmudzinski, M.; Skoracki, M.; Sikora, B. An updated checklist of quill mites of the family Syringophilidae (Acariformes: Prostigmata). Figshare. Dataset. 2021. Available online: https://doi.org/10.6084/m9.figshare.16529574.v1 (accessed on 20 October 2021).

2. Kethley, J.B. A revision of the family Syringophilidae (Prostigmata: Acarina). Contrib. Am. Entomol. Inst. 1970, 6, 1-76.

3. Skoracki, M. Quill mites (Acari: Syringophilidae) of the Palaearctic region. Zootaxa 2011, 2840, 1-416. [CrossRef]

4. Skoracki, M.; Glowska, E.; Bochkov, A.V. Phylogeny of quill mites of the family Syringophilidae (Acari: Prostigmata) based on their external morphology. Eur. J. Entomol. 2013, 110, 663-675. [CrossRef]

5. Skoracki, M.; Sikora, B.; Spicer, G.S. A review of the subfamily Picobiinae Johnston and Kethley, 1973 (Acariformes: Prostigmata: Syringophilidae). Zootaxa 2016, 4113, 1-95. [CrossRef] [PubMed]

6. Fry, C.H. Family Meropidae (bee-eaters). In Handbook of the Birds of the World, 1st ed.; del Hoyo, J., Elliot, A., Sargatal, J., Eds.; Mousebirds to Hornbills: Lynx Ediciones, Barcelona, Spain, 2001; Volume 6.

7. Clements, J.F.; Schulenberg, T.S.; Iliff, M.J.; Roberson, D.; Fredericks, T.A.; Sullivan, B.L.; Wood, C.L. The eBird/Clements Checklist of Birds of the World. Ver. 2020. Available online: http://www.birds.cornell.edu/clementschecklist/download/ (accessed on 20 October 2021).

8. Winkler, D.W.; Billerman, S.M.; Lovette, I.J. Bee-eaters (Meropidae). In Birds of the World, version: 1.0; Billerman, S.M., Keeney, B.K., Rodewald, P.G., Eds.; Cornell Lab of Ornithology: Ithaca, NY, USA, 2020. Available online: https://doi.org/10.2173/bow. meropi1.01 (accessed on 30 October 2021).

9. Marks, B.D.; Weckstein, J.; Moyle, R.G. Molecular phylogenetics of the bee-eaters (Aves: Meropidae) based on nuclear and mitochondrial DNA sequence data. Mol. Phyl. Evol. 2007, 45, 23-32. [CrossRef]

10. Carneiro de Melo Moura, C.; Bastian, H.V.; Bastian, A.; Wang, E.; Wang, X.; Wink, M.; Wink, M. Pliocene origin, ice ages and postglacial population expansion have influenced a panmictic phylogeography of the European Bee-Eater Merops apiaster. Diversity 2019, 11, 12. [CrossRef]

11. Skoracki, M.; Dabert, J. Syringophilopsis albicollisi, a new species of the quill mite of the family Syringophilidae Lavoipierre, 1953 (Acari: Prostigmata). Acarina 2000, 8, 59-63.

12. Skoracki, M.; Dabert, J. The quill mites of the genus Syringophilopsis Kethley, 1970 (Acari, Syringophilidae) from African birds. Acarina 2001, 9, 105-112.

13. Skoracki, M.; Hromada, M.; Sikora, B. Castosyringophilus meropis sp. n. (Acariformes: Syringophilidae)—A new quill mite species parasitising the world population of Merops apiaster Linnaeus (Coraciiformes: Meropidae). Folia Parasitol. 2017, 64, 024. [CrossRef]

14. Skoracki, M.; Hromada, M.; Kaszewska, K.; Sikora, B. Females of the quill mite genera Peristerophila and Castosyringophilus (Acariformes: Syringophilidae) are two morphological forms: ontogenetic and population evidences. Syst. Appl. Acarol. 2020, 25, 1803-1820.

15. Grandjean, F. Les segments postlarvaires de l'hysterosoma chez les oribates (Acariens). Bull. Soc. Zool. France 1939, 64, $273-284$.

16. Kethley, J.B. Acarina: Prostigmata (Actinedida). In Soil Biology Guide; Dindal, D.L., Ed.; Wiley and Sons: New York, NY, USA, 1990; pp. 667-754.

17. Grandjean, F. Observations sure les Acariens de la famille des Stigmaeidae. Archiv. Sci. Phys. Nat. 1944, 26, $103-131$.

18. Jetz, W.; Thomas, G.H.; Joy, J.B.; Hartmann, K.; Mooers, A.O. The global diversity of birds in space and time. Nature 2012, 491, 444-448. [CrossRef] [PubMed] 
19. Møller, A.P.; Díaz, M.; Flensted-Jensen, E.; Grim, T.; Ibáñez-Álamo, J.D.; Jokimäki, J. Urbanized birds have superior establishment success in novel environments. Oecologia 2015, 178, 943-950. [CrossRef]

20. Mikula, P.; Morelli, F.; Lučan, R.K.; Jones, D.N.; Tryjanowski, P. Bats as prey of diurnal birds: A global perspective. Mamm. Rev. 2016, 46, 160-174. [CrossRef]

21. Hromada, M.; Klimovicova, M.; Unsoeld, M.; Skoracki, M. Host-parasite relationships in the system composed by cuckoos and quill mites. Syst. Appl. Acarol. 2016, 21, 528-536.

22. Skoracki, M.; Sikora, B.; Jerzak, L.; Hromada, M. Tanopicobia gen. nov., a new genus of quill mites, its phylogenetic placement in the subfamily Picobiinae (Acariformes: Syringophilidae) and picobiine relationships with avian hosts. PLoS ONE 2020, 15, e0225982. [CrossRef] [PubMed]

23. Drummond, A.J.; Rambaut, A. BEAST: Bayesian evolutionary analysis by sampling trees. BMC Evol. Biol. 2007, 7, 214. [CrossRef]

24. Rambaut, A. FigTree v1.4.4. 2018. Available online: http:/ / tree.bio.ed.ac.uk/software/figtree/ (accessed on 20 May 2021).

25. BirdLife International and Nature Serve. Bird Species Distribution Maps of the World; BirdLife International: Cambridge, UK; NatureServe: Arlington, TX, USA, 2014.

26. Vuilleumier, F. Ernst Mayr's biogeography: A lifetime of study. Ornithol. Monogr. 2005, 58, 58-72. [CrossRef]

27. Mayr, E. Populations, Species, and Evolution: An Abridgment of Animal Species and Evolution; Belknap Press of Harvard University Press: London, UK, 1970; p. 453.

28. Skoracki, M.; Hromada, M.; Sikora, B. Quill mites of the family Syringophilidae (Acariformes: Prostigmata) parasitizing coraciiform birds (Aves: Coraciiformes). Zootaxa 2020, 4802, 169-181. [CrossRef]

29. Fahrenholz, H. Ectoparasiten und Abstammungslehre. Zool. Anz. 1913, 41, 371-374.

30. Eichler, W. Wirtsspezifitat und stammesgeschichtliche Gleichlaufigkeit bei Parasiten im allgemeinen und bei Mallophagen im besonderen. Zool. Anz. 1941, 132, 254-262.

31. Sibley, C.G.; Ahlquist, J.E. Phylogeny and Classification of Birds; Yale University Press: New Haven, CT, USA, 1990; pp. xxiii + 976.

32. Sibley, C.G.; Monroe, B.L., Jr. Distribution and Taxonomy of Birds of the World; Yale University Press: New Haven, CT, USA, 1990; p. 1111.

33. Sibley, C.G.; Monroe, B.L., Jr. A Supplement to Distribution and Taxonomy of Birds of the World; Yale University Press: New Haven, CT, USA, 1993; p. 108.

34. Dickinson, E.C. The Howard \& Moore Complete Checklist of the Birds of the World, 3rd ed.; Christopher Helm: London, UK, 2003; p. 1039.

35. Collar, N.J. Species limits in some Philippine birds including the Greater Flameback Chrysocolaptes lucidus. Forktail 2011, 27, 29-38.

36. Del Hoyo, J.; Collar, N.J.; Christie, D.A.; Elliott, A.; Fishpool, L.D.C. HBW and Bird Life International Illustrated Checklist of the Birds; Lynx Ediciouns: Barcelona, Spain, 2016; Volume 1, p. 904.

37. Huang, Z.H.; Tu, F.Y.; Murphy, R.W. Analysis of the complete mitogenome of Oriental turtle dove (Streptopelia orientalis) and implications for species divergence. Biochem. Syst. Ecol. 2016, 65, 209-213. [CrossRef]

38. Del Hoyo, J.; Collar, N.; Kirwan, G.M. Rufous-crowned Bee-eater (Merops americanus). In Birds of the World, version: 1.0; del Hoyo, J., Elliott, A., Sargatal, J., Christie, D.A., de Juana, E., Eds.; Cornell Lab of Ornithology: Ithaca, NY, USA, 2020. Available online: https: / / doi.org/10.2173/bow.rucbee1.01 (accessed on 30 October 2021).

39. Fry, H.; Boesman, P.F.D. Blue-tailed Bee-eater (Merops philippinus). In Birds of the World, version: 1.0; del Hoyo, J., Elliott, A., Sargatal, J., Christie, D.A., de Juana, E., Eds.; Cornell Lab of Ornithology: Ithaca, NY, USA, 2020. Available online: https: / / doi.org/10.2173/bow.btbeat1.01 (accessed on 30 October 2021).

40. Woodall, P.F. Collared Kingfisher (Todiramphus chloris). In Birds of the World, version: 1.0; Billerman, S.M., Keeney, B.K., Rodewald, P.G., Schulenberg, T.S., Eds.; Cornell Lab of Ornithology: Ithaca, NY, USA, 2020. Available online: https://doi.org/10.2173/bow. colkin1.01 (accessed on 30 October 2021).

41. Skoracki, M.; Kosicki, J.Z.; Kwiecinski, Z. Distribution of the parasitic mite Bubophilus aegolius sp. n. (Acariformes: Syringophilidae) on the Boreal Owl Aegolius funereus (L) (Strigiformes: Strigidae) and the low effectiveness of infestation. Eur. Zool. J. 2021, 88, 352-362. [CrossRef]

42. Kaszewska-Gilas, K.; Kosicki, J.Z.; Hromada, M.; Skoracki, M. Global studies of the host-parasite relationships between ectoparasitic mites of the family Syringophilidae and birds of the order Columbiformes. Animals 2021, 11, 3392. [CrossRef]

43. Skoracki, M.; Hromada, M.; Prevuznakova, P.; Wamiti, W. Mites of the family Syringophilidae (Acariformes: Cheyletoidea) parasitizing waxbills of the genus Estrilda (Passeriformes: Estrildidae). Syst. Appl. Acarol. 2019, 24, 1799-1808.

44. Skoracki, M.; Hromada, M.; Zmudzinski, M.; Unsoeld, M.; Sikora, B. Parasitic quill mites of the family Syringophilidae (Acariformes: Prostigmata) associated with Sub Saharan Sunbirds (Passeriformes: Nectariniidae): Species composition and host-parasite relationships. J. Med. Entomol. 2018, 55, 1464-1477. [CrossRef] [PubMed]

45. Grossi, A.; Proctor, H. The distribution of quill mites (Betasyringophiloidus seiuri) among flight feathers of the ovenbird (Seiurus aurocapilla). J. Parasitol. 2020, 106, 82-89. [CrossRef]

46. Skoracki, M.; Michalik, J.; Sikora, B. Prevalence and habitat preference of quill mites (Acari, Syringophilidae) parasitizing forest passerine birds in Poland. Acta Parasitol. 2010, 55, 188-193. [CrossRef]

47. Skirnisson, K.; Nielsen, Ó.K. Quill mite infestation of rock ptarmigan Lagopus muta (Aves: Phasianidae) in relation to year and host age, sex, body condition, and density. Parasitol. Res. 2019, 118, 2643-2650. [CrossRef] 